\title{
ISOLATION, PARTIAL PURIFICATION AND CHARACTERIZATION OF PHOSPHOLIPASE A2 FROM Naja katiensis VENOM
}

\author{
Okechukwu, C.F. ${ }^{2}$, Shamsudeen, P.L. ${ }^{1}$, Bala, R.K. ${ }^{1}{ }$, Kurfi, B.G. ${ }^{2}$ and Abdulazeez, \\ A.M. ${ }^{1}$ \\ ${ }^{1}$ Center for Biotechnology Research, Bayero University, Kano \\ ${ }^{2}$ Department of Biochemistry, Faculty of Basic Medical Sciences, Bayero University, Kano \\ *Corresponding author: rkbala.cbr@buk.edu.ng, +2348039120564
}

\begin{abstract}
The most effective and acceptable therapy for snakebite victims is the immediate administration of antivenin which is limited by problems of hypersensitivity reactions in some individuals and its inability to resolve the local effects of the venom. The aim of this study was to isolate, partially purify and characterize phospholipase $A_{2}$ from Naja Katiensis venom. Phospholipase $A_{2}$ was partially purified via a two-step process; gel filtration on Sephadex G-75 and ion exchange chromatography using CM Sephadex, and subjected to SDS-PAGE analysis. From the results, the specific activity of the partially purified $P_{2 A_{2}}$ decreased from $0.67 \mu \mathrm{mol} / \mathrm{min} / \mathrm{mg}$ in crude venom to $0.29 \mu \mathrm{mol} / \mathrm{min} / \mathrm{mg}$ after ion exchange chromatography with a yield of $5 \%$ and purification fold of 0.43 . The optimum temperature of the purified PLA $\mathrm{A}_{2}$ was found to be $35^{\circ} \mathrm{C}$ and optimum p.H of 7. Initial velocity studies for the determination of kinetic constants using L-a-lecithin as substrate revealed a $K_{m}$ of $1.47 \mathrm{mg} / \mathrm{ml}$ and $V_{\max }$ of $3.32 \mu \mathrm{moles} / \mathrm{min} / \mathrm{mg}$. The sodium dodecyl sulphate polyacrylamide gel electrophoresis of the purified PLA $A_{2}$ showed a distinct band with molecular weight estimated to be 14KDa. In conclusion, the present study shows that phospholipase $A_{2}$ was isolated, purified and characterized. This may serve as a promising candidate for future development of a novel anti-venin drug.

Keywords: Naja Katiensis, Snakebite, Phospholipase $A_{2,}$ Isolation
\end{abstract}

\section{INTRODUCTION}

Snakebite envenomation is of public health concern as it results in mortality and chronic morbidity especially in the rural communities of the developing world (Harrison et al., 2009). Report has shown that there are as many as 4.5 to 5 million snake bites/year globally, resulting in 2.5 million envenomings, 125,000 deaths and perhaps over 300,000 with permanent disabilities (Chippaux, 1998). The venoms released by snakes after a bite are composed of complex mixture of active substances, mainly peptides and proteins which are able to interfere with the course of several biological processes including thrombosis by affecting platelet aggregation and blood coagulation. Some of these proteins include enzymes like phospholipase $\mathrm{A}_{2}$ and metalloprotease (Echi Tab, 2008).

Phospholipase $A_{2}\left(P_{2}\right.$, EC 3.1.1.4) is an enzyme that hydrolyzes the fatty acid ester bond at position 2 of the 1,2-diacyl-snphosphoglycerides to release free fatty acid and lysophospholipid. The fatty acid so formed may act as either second messenger or a precursor of eicosanoids, known to be key factors in mammalian tissues, arthropods and in snake venom, based on their source, amino acid sequence, chain length and disulfide bond patterns. Some clinical effects following snakebite are due to phospholipase $A_{2}$, which are among the major components of venoms. Although these enzymes share a common catalytic activity and similar structural features with non-toxic mammalian pancreatic enzymes, they also promote a wide variety of pathological symptoms in animals, such as cardiotoxicity, myotoxicity, anticoagulant activity, hemolysis, edema, convulsant activity as well as induction of pre-synaptic toxicity (Warrel, 2008).

Snake venoms are particularly rich in $\mathrm{PLA}_{2} \mathrm{~S}$ and some of them contain more than one isoform of this enzyme. Many of these isoenzymes have similar molecular weights but can be differentiated by purification methods. Snake venom $\mathrm{PLA}_{2}$ is able to induce several biological effects and this diversity of physiological functions of $\mathrm{PLA}_{2}$ isoenzymes from snake venoms is very important for the production of antivenoms. Although, studies have shown that snake bites resulting from Naja katiensis is low in Nigeria (Yusuf, 2015), it is pertinent to understand the accelerated evolution of this enzyme in the Elapidae venomas. 
BAJOPAS Volume 13 Number 2, December, 2020

Information concerning this enzyme in Naja katiensis is scarce and could be important in antivenom design. Therefore, this study aims to partially purify and characterize PLA $\mathrm{A}_{2}$ from the venom of Naja katiensis.

\section{MATERIALS AND METHODS MATERIALS \\ Equipment}

Centrifuge, spectrophotometer, $\mathrm{pH}$ metre, water bath, incubator, $5 \mathrm{ml}$ syringes, chromatography column, beakers, conical flasks, measuring cylinders, plane container, glass wool, micro pipettes, glass rods, retort stand, refrigerator, cuvette, weighing balance

\section{Chemicals and Reagents}

Lyophilized Najakatiensis venom, sephadex G75, sephadex C-50, Lecithin from egg yolk, deionized water and TCA.

\section{METHODS}

\section{Preparation of Crude Venom}

About $0.03 \mathrm{mg}$ of the crude venom was dissolved in phosphate buffer $(20 \mathrm{Mm}, \mathrm{pH} 7.60)$, mixed and immediately centrifuged at $3000 \mathrm{x} \mathrm{g}$ for 10 minutes and stored at $20^{\circ} \mathrm{C}$ until needed.

\section{Gel-filtration on Sephadex G-75}

The gel was prepared by dissolving $2 \mathrm{~g}$ of sephadex G-75 in $50 \mathrm{ml}$ ammonium acetate buffer, pH 7.4 for 24 hours at room temperature and mixed with a glass rod. The gel was then poured into a column packed with glass wool at the bottom. The column was first equilibrated with ammonium acetate buffer, $\mathrm{pH} 7.4$, before the sample was applied. Crude venom $(0.03 \mathrm{mg})$ was dissolved in $3 \mathrm{ml}$ ammonium acetate buffer, $\mathrm{pH} 7.4$ in a beaker. Thirty (30) fractions at a flow rate of $3 \mathrm{ml}$ per minute were collected and analyzed for total protein and enzyme activity. The fractions showing high activity were pooled together and further purified by ion exchange chromatography.

\section{Ion-exchange chromatography on CM Sephadex}

The anion-exchanger was prepared by dissolving $2 \mathrm{~g}$ of C- 50 sephadex in $50 \mathrm{ml}$ of Tris buffer, $\mathrm{pH}$ 8.2. The gel was then poured into a column. The fractions obtained from the gel-filtration step were pooled together and the sample $(3 \mathrm{ml})$ was loaded onto the column and eluted with a linear gradient of sodium chloride solution $(0.00,0.01$, $0.15,0.20,0.25$, and 0.30). Twenty-four fractions were collected $5 \mathrm{ml}$ for each concentration, at a flow rate of $5 \mathrm{ml} / 5$ minute and analyzed for total protein and enzyme activity. The most active fractions were collected and pooled together.

\section{Determination of PLA $\mathbf{A}_{\mathbf{2}}$ Activity}

The PLA $\mathrm{A}_{2}$ activity was determined by Habermann and Neumann (1954) method. Briefly, 25uL of
$1 \mathrm{~g} \mathrm{/ml} \mathrm{L} \mathrm{a-lecithin} \mathrm{was} \mathrm{incubated} \mathrm{with} 10 \mathrm{uL}$ of the partially purified enzyme from Naja katientsis venom for 10 mins at $37^{\circ} \mathrm{C}$. The reaction was then terminated by immersing the tube in water bath for 2 mins and the amount of released free fatty acid measured titrimetrically at $\mathrm{pH} \quad 8.0$ using $20 \mathrm{mM} \mathrm{NaOH}$ and phenolphthaline indicator. The activity of phospholipase $A_{2}$ was defined as the amount of enzymes that hydrolises $1 \mu \mathrm{mol}$ of $L$ a-lecithin per minute under standard conditions

\section{Determination of Protein Content}

Content of the protein in the assay was determined according to Bradford (1976) method using Serum Bovine Albumin (BSA) as standard and the concentration was expressed in milligram per milliliter $(\mathrm{mg} / \mathrm{ml})$.

Characterization of Partially-purified PLA from Naja Katiensis Venom

Sodium Dodecyl Sulphate-Polyacrylamide Gel Electrophoresis (SDS-PAGE)

To investigate the apparent molecular weight of the partially purified enzyme, sodium dodecyl sulphate polyacrylamide gel electrophoresis carried out using $14 \%$ gel in SDS-Tris-glycine buffer, and band was identified by staining with comassie brilliant blue R250 (Lammeli 1970)

\section{Effect of $\mathrm{pH}$ and temperature}

The effect of temperature on the activity of partially purified $\mathrm{PLA}_{2}$ was measured at various temperatures from $20^{\circ} \mathrm{C}$ to $60^{\circ} \mathrm{C}$ and the effect of $\mathrm{pH}$ was as well studied by varying the $\mathrm{pH}$ from 2 to 10 . Briefly, L-a Lecithin was incubated for $15 \mathrm{mins}$ at different temperature, and the reaction was terminated by immersing the tube in a boiling water bath for 2 mins. The amount of released free fatty acid was measured titrimetrically at $\mathrm{pH} 8.0$ using $20 \mathrm{mM}$ sodium hydroxide and phenolphthalein indicator, after centrifugation at $1,600 \mathrm{~g}$ for 10 mins; the absorbance of the supernatant was measured at $280 \mathrm{~nm}$.

\section{Initial velocity studies}

The sample was assayed using various L-a Lecithin concentrations ( $1 \%$ to $5 \%$ ). Briefly, $100 \mu \mathrm{L}$ of the enzyme were added to the buffer solution. $0.1 \mathrm{M}$ Tris- $\mathrm{HCl}, \mathrm{pH} 9.0$, and the final volume was adjusted to $250 \mu \mathrm{L}$, followed by $750 \mu \mathrm{L}$ Of L-a Lecithin (1\% to 5\%) and incubated for $15 \mathrm{mins}$ at different temperatures as stated above, the reaction was terminated by adding $1.5 \mathrm{ml}$ of $30 \%$ TCA, after centrifugation at $1,600 \mathrm{~g}$ for $10 \mathrm{mins}$, the absorbance of the supernatant was measured at $280 \mathrm{~nm}$. The Lineweaver-Burk plot was used to determine the kinetic parameters $\mathrm{K}_{\mathrm{m}}$ and $\mathrm{V}_{\max }$. 
BAJOPAS Volume 13 Number 2, December, 2020 RESULTS AND DISCUSSION

Partial purification of Phospholipase $\mathbf{A}_{2}$ Table I shows the results of the partial purification of phospholipase $\mathrm{A}_{2}$ from Naja Katiensis venom. The enzyme was purified via two steps: Gel filtration using G-75 and ion exchange chromatography using CM-Sephadex. From the results, the crude venom had a specific activity of $0.67 \mu \mathrm{mol} / \mathrm{min} / \mathrm{mg}$ at $100 \%$ yield. After gel filtration, it was $0.546 \mu \mathrm{mol} / \mathrm{min} / \mathrm{mg}$ at $10 \%$ yield. On further purification the specific activity decrease to $0.290 \mu \mathrm{mol} / \mathrm{min} / \mathrm{mg}$ at $5 \%$ yield with a purification fold of 0.43 .

Figure 1 shows the result of the gel filtration, of which fractions with highest enzyme activity were pooled together for purification. The pooled fractions from gel filtration were subjected to ion exchange chromatography using CM-Sephadex, andeluted at a linear gradient of sodium chloride solution $(0.00,0.01$, $0.15,0.20,0.25$, and 0.30). Fraction 23 had the highest activity (Figure
2).

Table I: Purification table of phospholipase $\mathrm{A}_{2}$ from Naja katiensis venom

\begin{tabular}{llllll}
\hline $\begin{array}{l}\text { PURIFICATION } \\
\text { STEPS }\end{array}$ & $\begin{array}{l}\text { TOTAL } \\
\text { PROTEIN } \\
(\mathbf{m g})\end{array}$ & $\begin{array}{l}\text { TOTAL } \\
\text { ACTIVITY } \\
(\boldsymbol{\mu m o l} / \mathbf{m i n})\end{array}$ & $\begin{array}{l}\text { SPECIFIC } \\
\begin{array}{l}\text { ACTIVITY } \\
(\boldsymbol{\mu m o l} / \mathbf{m i n} / \mathbf{m g}\end{array}\end{array}$ & $\begin{array}{l}\text { YEILD } \\
(\%)\end{array}$ & $\begin{array}{l}\text { PURIFICATIO } \\
\text { NoLD }\end{array}$ \\
\hline $\begin{array}{l}\text { Crude venom } \\
\text { Sephadex G- }\end{array}$ & 3.00 & 2.00 & 0.67 & 100 & 1 \\
$\begin{array}{l}\text { 75 } \\
\text { CM- sephadex }\end{array}$ & 0.3657 & 0.2 & 0.546 & 10 & 0.816 \\
\hline
\end{tabular}

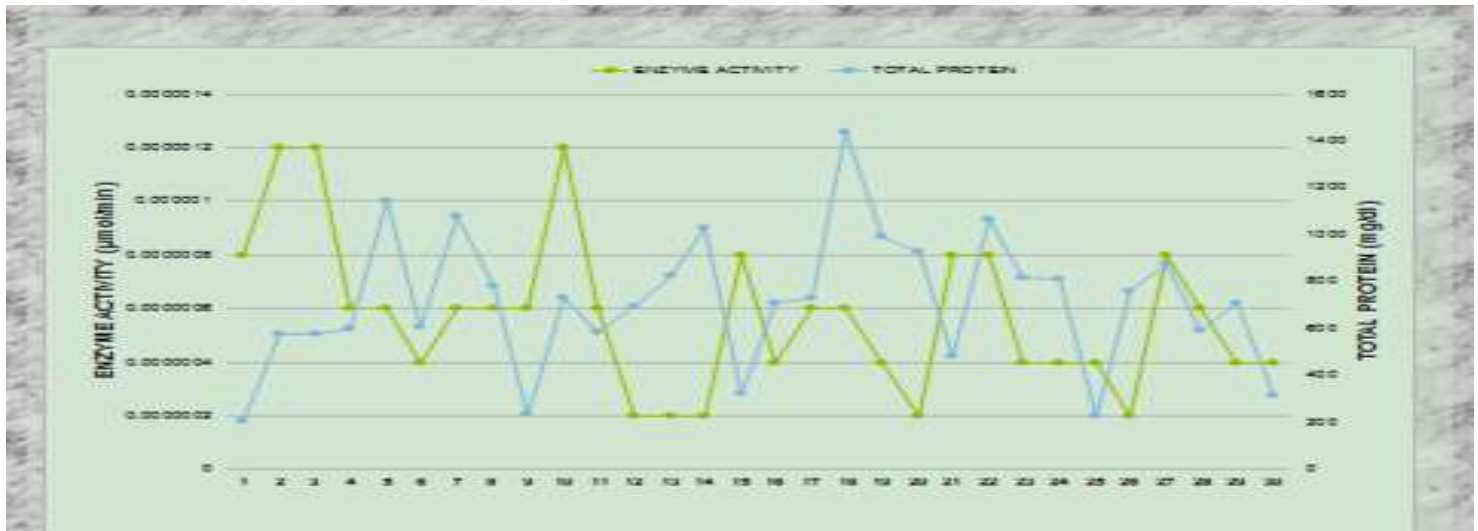

Figure1: Elution profile of Phospholipase $A_{2}$ from $N$. katiensis venom aftersphadex G-75 gel filtration chromatography

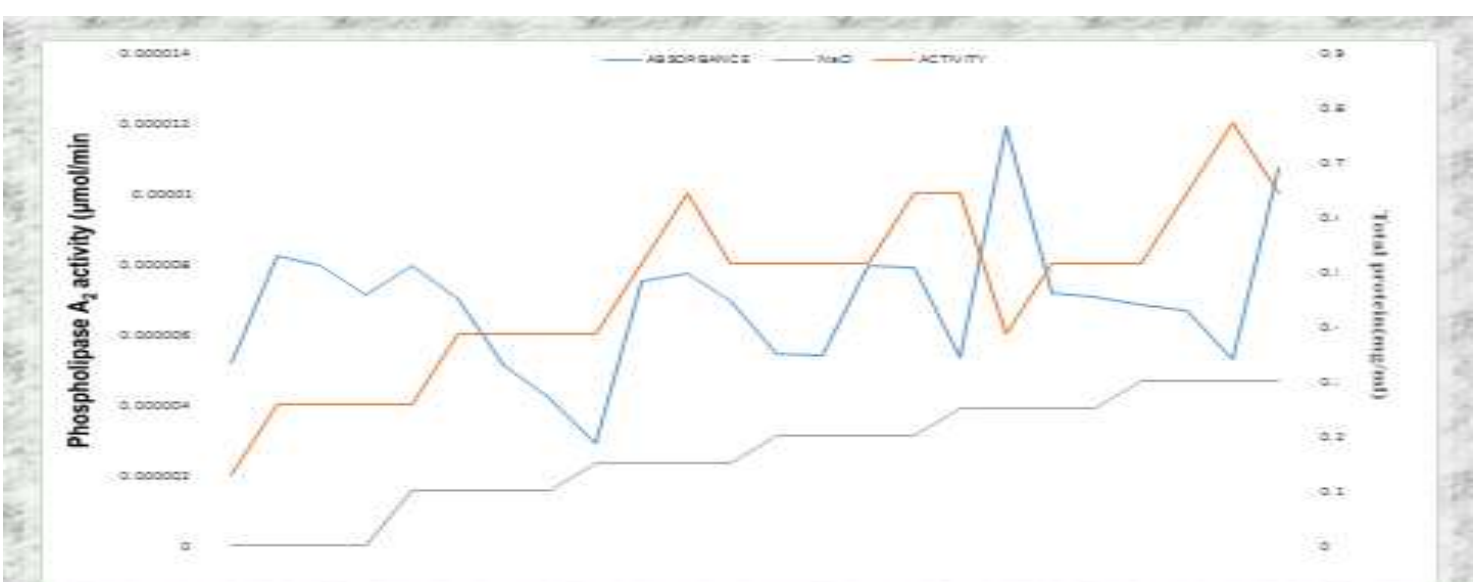

Figure2: Elution profile of Phospholipase $\mathrm{A}_{2}$ from $N$. katiensisvenm from $\mathrm{CM}$-sephadex ion exchange chromatography 
BAJOPAS Volume 13 Number 2, December, 2020

Effect of temperature and $\mathrm{pH}$ on the activity of the partially purified phospholipase $A_{2}$

The activity of the partially purified phospholipase $\mathrm{A}_{2}$ increased as temperature increased from $20^{\circ} \mathrm{C}$ up to a temperature of $35^{\circ} \mathrm{C}$. However, decreased in activity was

observed as the temperature increased (Figure 3). The activity of the partially purified Phospholipase $A_{2}$ was found to increase with increasing $\mathrm{pH}$ until it reached $\mathrm{pH} \mathrm{7,} \mathrm{where} \mathrm{the}$ activity was highest. After which increases in $\mathrm{pH}$ resulted in further decrease in activity (Figure 4).

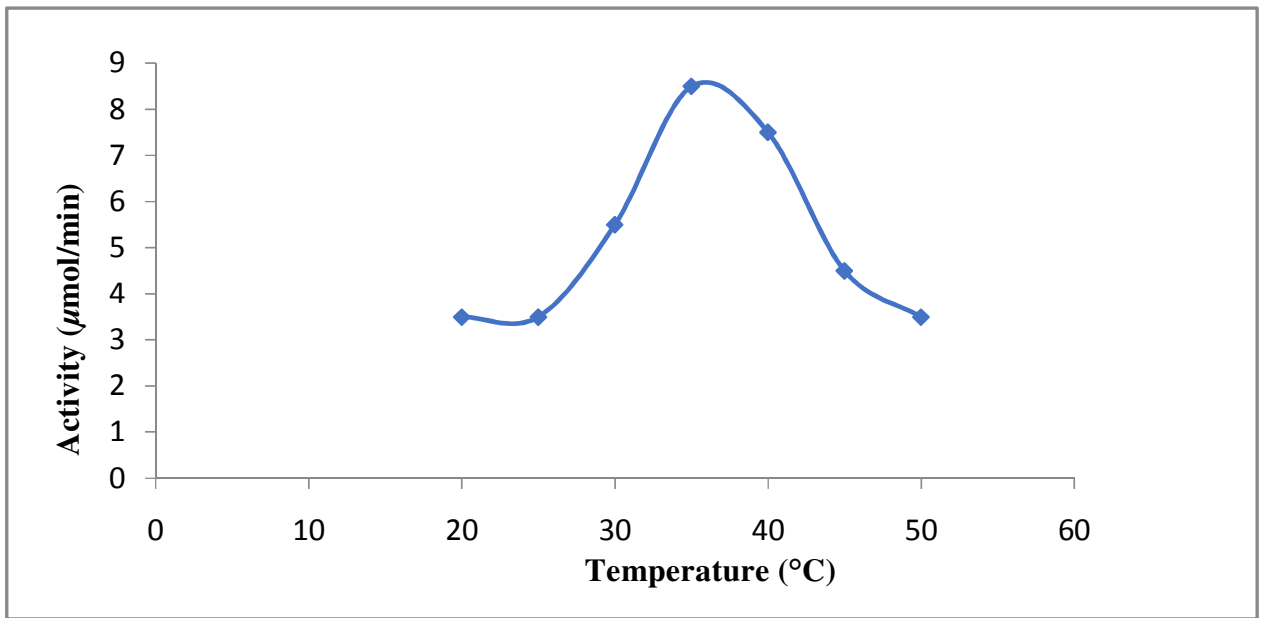

Figure3: Effect of temperature on the activity of the partially purified phospholipase $\mathrm{A}_{2}$ from $N$. katiensis venom.

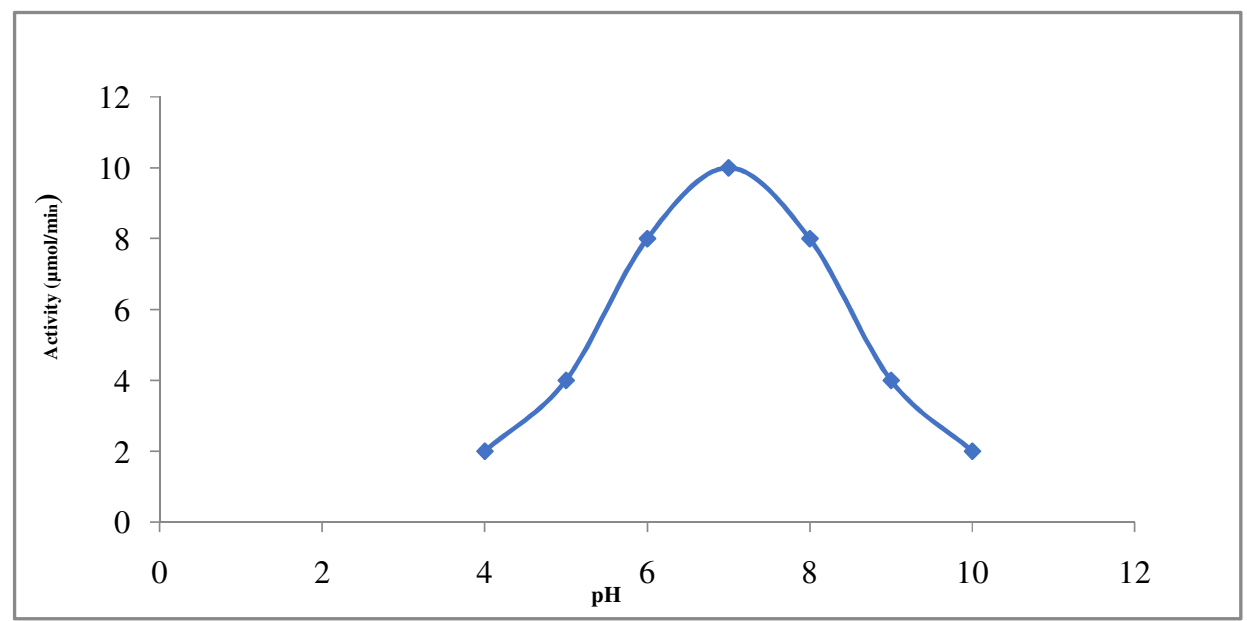

Figure 4: Effect of $\mathrm{pH}$ on the activity of the partially purified phospholipase $\mathrm{A}_{2}$ from N. Katiensis venom

\section{KINETIC STUDY}

Initial velocity data were used to compute the kinetic parameters of the enzyme. The $\mathrm{Km}$ of the partially purified PLA $\mathrm{A}_{2}$ enzyme of $12.6 \mathrm{mg} / \mathrm{ml}$ and Vmax of 3.32 umoles/min were obtained.

\section{SDS-PAGE}

The apparent molecular weight of the partially purified enzyme was estimated from results of sodium dodecyl sulphate-polyacrylamide elecotrophoresis (SDS-PAGE) and when compared to the molecular marker, the purified enzyme had a molecular weight approximated to be $14 \mathrm{KDa} \quad$ (figure 5). 


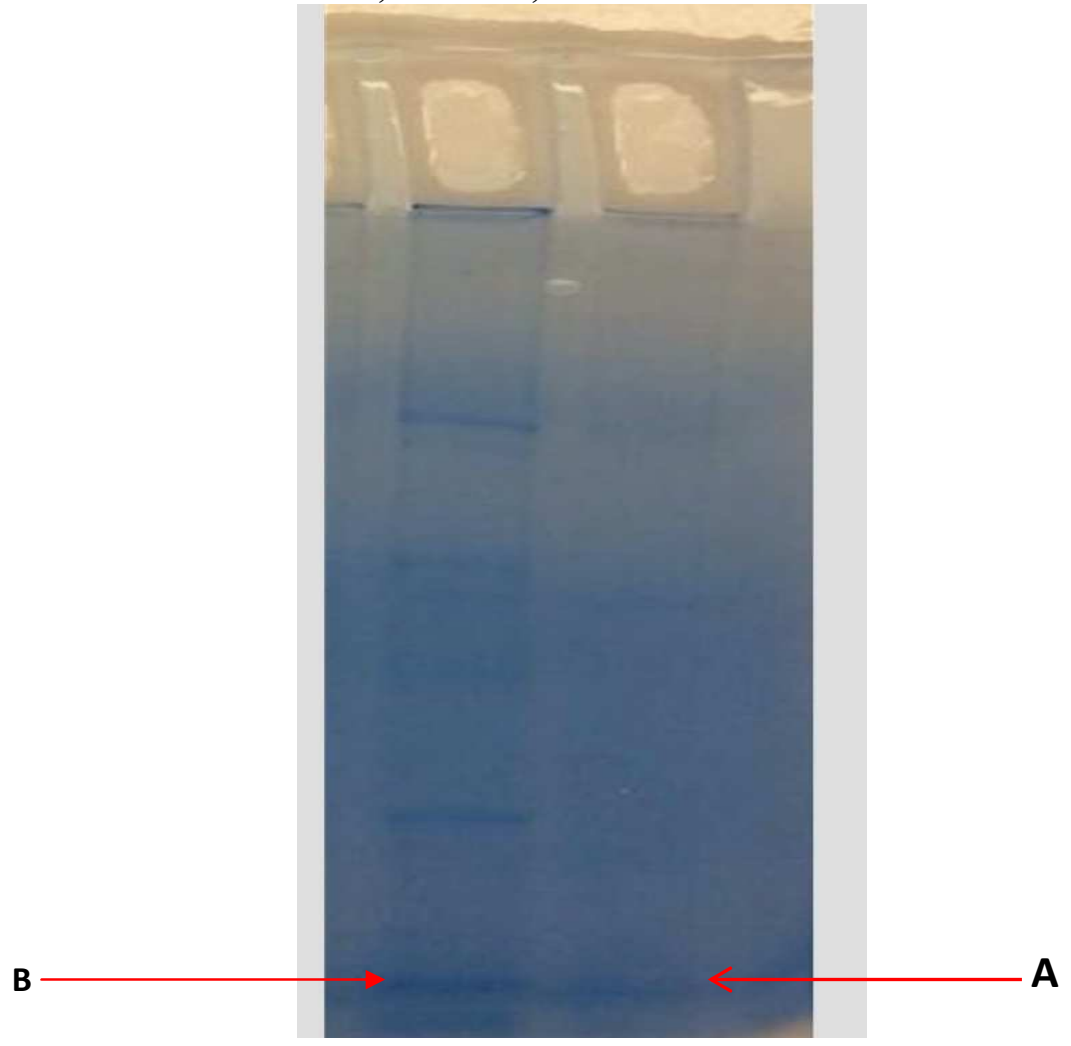

Figure 5: Electrophoregram of partially purified phospholipase $A_{2}$ from $N$. katiensis venom on polyacrylamide gel

usingcoomassie brilliant blue staining.

Band $A$ represents partially purified $\mathrm{PLA}_{2}$ with an estimated molecular weight of $14 \mathrm{kDa}$

Band B molecular marker

\section{DISCUSSION}

Toxicological properties of snakebite are thought to be associated with enzymes especially phospholipase $A_{2}\left(P L A_{2}\right)$, which is found to be its most toxic component. Considering the role of $\mathrm{PLA}_{2}$ in envenomation, understanding the characteristics of the enzyme from snake venom has raised concern for venom researchers, as it would help in the production of effective therapeutic antivenins. In this study, Naja Katiensis venom which belongs to the class II $\mathrm{PLA}_{2}$ predominantly found in viperidae snakes was isolated and partially purified. The specific activity of the partially purified $\mathrm{PLA}_{2}$ from Naja Katiensis decreased from 0.67 to $0.29 \mu \mathrm{min} / \mathrm{mg}$ after ion exchange chromatography with a purification fold of 0.43 , and $5 \%$ yield. Activity of $0.29 \mu \mathrm{mole} / \mathrm{min} / \mathrm{mg}$ is similar to that found in
Naja siamensis, and Naja melanoleuca but different from Naja mosambica $(0.47$ $\mu \mathrm{mole} / \mathrm{min} / \mathrm{mg}$ ) (William, 1998), Naja naja (0.16 $\mu \mathrm{mole} / \mathrm{min} / \mathrm{mg}$ ) (Pugh, et al, 1980), and Naja pallida $(0.67 \mu \mathrm{mole} / \mathrm{min} / \mathrm{mg}$ ) (Aird, 2002).

The maximum activity occurred at $35^{\circ} \mathrm{C}$, but activity decreased at $20^{\circ} \mathrm{C}$ and $50^{\circ} \mathrm{C}$ which is similar to the activity of Bothriopsis taeniata which the maximum velocity was obtained between $35^{\circ} \mathrm{C}$ and $40^{\circ} \mathrm{C}$ and decrease at $20^{\circ} \mathrm{C}$ (Vargas et al., 2014).

\section{CONCLUSION}

From this study, Phospholipase $A_{2}$ was partially purified and characterized by docking studies from Naja katiensis venom. This may be used to as a promising enzyme to develop a novel antivenin drug. 
BAJOPAS Volume 13 Number 2, December, 2020 REFERENCES

Aird, S.D. (2002). Ophidian envenomation strategies and the role of purines. J. of Inter. Soc. on Toxicol., 40: 335-393.

Bradford, M.M., (1976). A rapid and sensitive method for the quantitation of microgram quantities of protein utilizing the principle of protein-dye binding. Anal. Biochem. 72: $248-254$.

Chippaux, J.P., Williams, V. and White, J. (1991). Snake venom variability: Methods of study, results and interpretation. J. of Inter. Soc. on Toxicol. 29:1279-1303.

Chippaux, J.P., 1998. Snake-bites: appraisal of the global situation. Bull. World Health Organ. 76, 515-524

Habib, A. G., Abubakar, S.B., Abubakar, I.S., Larnyang, S., Durfa, N., Nasidi, A. et al. (2015). Envenoming after carpet viper (Echisocellatus) Bite During pregnancy: Timely use of effective antivenom improves maternal and fetal outcomes. J. Trop. Med. and Interna. Health, 13 (9), 1-4.

Habermann, E. and Neumann, W. (1954). Egg yolk coagulation method. Physiol Chem, 297: $174-176$
Harrison, R.A., Hargraeves, A., Wagstaff, S.C.,Faragher, B., Lalloo, D.G. (2009). Snake envenoming: a disease of poverty. PLoS Negl. Trop. Dis., 3:e569

Lammeli, U. K. (1970). Cleavage of Structural Proteins during the assembly of the Head of Bacteriophage T4. Nature. 227: 680-685.

Pugh, R.N.H. and Theakston R.D.G., (1980). Incidence and Mortality of snakebite in savannah Nigeria. Lancet, 11(29): 11811183.

Vargas, F.F., Thalita R, Maria A.C., Lea R., Luis A.P., and Sergio M. (2014). Biochemical Characterization of a PLA2 Btae TX-I Isolated from Bothriopsis taeniata Snake Venom: A Pharmacological and Morphological Study. J. Clin. Toxicol, 4:3

Warrell, D.A. (2008). Unscrupulous marketing of snake bite Antivenoms in Africa and Papua New Guinea: Choosing the right product - what's in a name? Transactions of the Royal Society for Tropical Medicine and Hygiene, 102: 397 $-399$

William A. (1998). Venomous Snakes: A Safety Guide for Reptile Keepers. Herpetological Circular No. 26 Lawrence, Kansas $66047 . \quad$ U.S.A. 